\title{
ROZWAŻANIA O NARRACJI BUDOWANEJ WOKÓŁ ARGUMENTU: „W ŚWIETLE ARCHEOLOGII"1
}

\author{
NARRATION IN HISTORICAL ARCHAEOLOGY BUILT \\ AROUND THE ARGUMENT: \\ "IN THE LIGHT OF ARCHAEOLOGY"
}

\author{
Michat Sottysiak \\ https://orcid.org/0000-0002-0258-7381 \\ Interdisciplinary Centre of Archaeological Research IAE PAN Warszawa \\ Al. Solidarności 105, 00-140 Warszawa \\ mjksol@gmail.com
}

\begin{abstract}
In the light of archaeology..." means a statement or conclusion based on archaeological sources, its practice and theoretical models used in it. But the range of possibilities and persuasiveness of all such statements is very wide. A typical lack of contemporary historiographic literature is the writer's failure to define his own research attitude. Researchers also rarely want to confront their own subjectivity and define their views before they start presenting their explanations for the topic under study. This applies to both the research attitude, evaluation and purposefulness of the sources used, the scope of using the achievements and workshop of anthropology, and the issue of the narrative nature of archaeological writing itself.

The aim of this article is to discuss the need for a more substantive attention to theoretical assumptions in archaeological writing, especially in the aspect of creating a historiographic narrative in historical archaeology. While attention is put on belonging to a given theoretical trend, the issues of narrative, persuasive procedures and noticing the narrative style that is chosen are less frequently analyzed. These are very significant characteristics of a given text, as they are directly directed to the reader, i.e., the person to whom our research and conclusions are presented.
\end{abstract}

${ }^{1}$ Badania zostały sfinansowane ze środków Narodowego Centrum Nauki przyznanych w ramach finansowania stażu po uzyskaniu stopnia naukowego doktora na podstawie decyzji numer DEC-2014/12/S/ HS3/00013 (The research was funded by the National Science Center awarded in as part of financing the internship after obtaining a doctoral degree based on decision number DEC-2014/12 / S / HS3 / 00013). 
This text is, in accordance with the above considerations, also a commentary on the existing state and an attempt to draw attention to the need for the most conscious approach to one's own scientific workshop.

KEY WORDS: historical archaeology, archaeological narrative, “informant's mark” in archaeology

Narracja budowana wokół argumentu „w świetle archeologii” oznacza wypowiedź lub wniosek utworzony na bazie źródeł archeologicznych, jej praktyki i stosowanych w niej modeli teoretycznych. Zwrot ten znajdujemy w wielu tytułach i treści publikacji. Jednak zakres takich stwierdzeń, ich możliwości perswazyjne są bardzo szerokie. Dlatego wymaga to określenia i podania informacji o tym, jak wygląda podejście badawcze we wszelkich tekstach wykorzystujących tę swoistą argumentację czy wręcz słowo-klucz. Typowym problemem dzisiejszego piśmiennictwa historiograficznego jest brak zdefiniowania własnej postawy badawczej przez piszącego i częste odwoływanie się do metafor. Pomija się wręcz milczeniem kwestie czy przekonania wpływają na wnioskowania i sposób prowadzenia narracji w tekstach pisanych. Badacze rzadko to deklarują, kiedy chcą zmierzyć się z własną subiektywnością i określić swoje poglądy, zanim zaczną przedstawiać swoje objaśnienia badanego tematu (m.in. Marciniak, 2011, s. 163; Urbańczyk, 2014, s. 262). Tym samym należy określić, przynajmniej wstępnie, założenia teoretyczne dla danej pracy, aby łatwo było ocenić konsekwencje prezentowanych w niej poglądów, ujęć, modeli.

Celem niniejszego artykułu jest zwrócenie uwagi na założenia teoretyczne archeologów, szczególnie w aspekcie tworzenia narracji ${ }^{2}$ historiograficznej w archeologii historycznej, która bazuje na swoistych metaforach „oświetlania” wiedzy. Zwłaszcza że, jak pisał Jerzy Topolski i za nim wielu innych badaczy, narracja, tworzenie opowieści to najpowszechniejsza forma przedstawiania wyników badań w historiografii (Topolski, 2008, s. 385; Marciniak, 2013, s. 19). O ile zwraca się uwagę na przynależność do danego nurtu teoretycznego, to kwestie narracji, zabiegów perswazyjnych i dostrzeżenia płaszczyzny wyjaśniającej, jaką się wybiera, a także metafor, wokół których organizuje się wywód, rzadko są przedmiotem analizy. Są to jednak znaczące charakterystyki danego tekstu, ponieważ kierowane wprost do czytelnika, czyli osoby, której nasze badania i wnioski są przedstawiane.

\section{JAKA ARCHEOLOGIA - HUMANISTYCZNA, SPOLECZNA CZY MOŻE PRZYRODNICZA?}

Colin Renfrew i Paul Bahn napisali w swojej pracy, będącej swoistym kompendium wiedzy archeologicznej, że ,[a]rcheologia jest nauką tyleż przyrodniczą, co humanistyczną" (Renfrew, Bahn, 2002, s. 12). To proste stwierdzenie jasno pokazuje

\footnotetext{
${ }^{2}$ Należy jednak pamiętać za Jerzym Topolskim, że „Narracje (historyczne) nie są jednak prostą sumą zawartych w nich zdań. To, że poszczególne informacje w narracji mogą być prawdziwe, nie przesądza jeszcze o prawdziwości narracji jako całości” (Topolski, 2008, s. 377).
} 
problem i spektrum zagadnień, z jakimi musimy się obecnie mierzyć w archeologii. Problem samookreślenia stopnia scientyfikacji, humanizacji, antropologizacji, interdyscyplinarności itd. rodzi poważny kłopot już przy świadomości, w jakim kontekście będzie się przedstawiać wnioski i hipotezy. Ważne jest również, czy takie określenie rzeczywiście jest niezbędne w pracach archeologicznych, skoro wiele z nich nie ma jasno wyartykułowanych założeń badawczych.

Najważniejsze pytania dla wszelkich badań, nie tylko tych związanych z naukami humanistycznymi i społecznymi, są dwa: „co próbujemy odkryć?” i „,zemu wiedza ta służy?”. Namysł nad przedmiotem badań i sensem ich wykonywania często nie jest wyrażony w pracach, ponieważ wydaje się to niepotrzebne. Sens thumaczy się sam przez siebie, a trudno przecież przed podjęciem badań odpowiedzieć na pytanie, co się odkryje (Barnard, 2016, s. 31). To podejście niestety jest widoczne w archeologii, gdzie bardziej dokumentuje się odkrycia post factum, niż wychodzi się od pytania badawczego, zanim rozpocznie się prace badawcze. To bolączka wszystkich nauk historycznych do 1989 roku w naszym kraju. W Polsce do dziś pozostały zapewne złe wspomnienia z poprzedniego ustroju, kiedy to pojawiały się wystąpienia dotyczące badań, gdzie nie tylko sugerowano „co badać”, ale także ,jak badać”, co zaowocowało nieufnością do refleksji teoretycznej nad praktyką badań historycznych (Domańska, Stobiecki, Wiślicz, 2014, s. 88). Mało mamy też podobnych jak w historii postulatów, aby jak najszerzej uczyć szerokiego podejścia teoretycznego i jego stosowania.

Podobna sytuacja dotyczy odpowiedzi na pytanie, do czego można wykorzystać wyniki poszczególnych wykopalisk lub jak je umieścić w strukturze stanu wiedzy na dany temat (np. czy są potwierdzeniem jakichś wcześniejszych założeń itd.). Nie jest to zazwyczaj jasno artykułowane, co nie służy integracji wiedzy w danym zakresie. Cytat z Edwarda C. Harrisa podsumowuje to uproszczenie wręcz idealnie, a który pisze, że „Jedną z najstarszych pasji człowieka jest niewątpliwie kopanie $\mathrm{w}$ ziemi w poszukiwaniu cennych przedmiotów. Wykopaliska archeologiczne można określić jako jeden z ostatnich przejawów tej pasji” (Harris 1989, s. 14). Niestety kwestia szerszego wykorzystania wyników badań jest mniej priorytetowa. To zaś implikuje propozycję podziału na archeologów - terenowców i archeologów gabinetowych, która jest niewłaściwa z samego założenia, bo bez dobrej rejestracji źródeł żadne teoretyczne badania nie mają sensu i odwrotnie. Podobnie bez odpowiedniego przygotowania koncepcyjnego wszelkie wykopaliska zmienią się w chaotyczny rabunek artefaktów. Niszczy się przy tym liczne informacje dotyczące postrzegania stanowiska archeologicznego jako zespołu, pewnej całości obejmującej otoczenie, artefakty, kontekst itd., a nie tylko zbiór przedmiotów. Postuluje to chociażby Kazimierz Grążawski nawołujący również do większej refleksji i wsparcia archeologii przez koncepcje i modele historiograficzne (Grążawski, 2015, s. 166-167).

Również ograniczenie do „wykopalisk i ich opisania” przyczynia się do sytuacji, że istnieje skrajne podejście wprost uznające archeologię za „technikę (badawczą)", a nie dziedzinę wiedzy (Rączkowski, 2012, s. 369). Archeologia tak rozumiana ogranicza się do pozyskania źródeł i danych, które służą badaczom innych nauk do wnioskowania i interpretacji przeszłości (takim jak choćby historycy i antropolodzy; 
za: Rączkowski, 2012, s. 370). Takie podejście wsparte jest niekiedy przez mniej lub bardziej świadome przekonanie, że przyrost wiedzy w archeologii postępuje jedynie w wyniku nowych wykopalisk, a refleksja teoretyczna jest zbędna. „Archeolog-gabinetowiec" staje się tym samym kimś nie w pełni wykonującym swoje zadania, swój zawód. Specyfika praktykowania zawodu archeologa stawia bowiem bardziej na eksplorację i odkrywanie coraz to nowych artefaktów, a nie na opracowanie i wnioskowania na bazie dotychczas zgromadzonych danych i źródeł. Zgodnie z tym archeolog jest „poszukiwaczem”, a nie badaczem, co i tak brzmi lepiej niż podwykonawca-ekspert na inwestycjach, dokonujący często dramatycznych wyborów, co zadokumentować i zachować w ramach niewystarczającego czasu, jaki daje inwestor podczas prac budowlanych. Opinia, że wykopaliska są wręcz synonimem archeologii, pojawiła się jeszcze u zarania dziejów tej nauki (XIX w.!) (Rączkowski, 2012, s. 373), a więc samo stwierdzenie o ciągłej potrzebie pozyskania nowych źródeł wydaje się anachronizmem, który nie wspiera jakościowo archeologii jako nauki oraz zniechęca do pełniejszego wykorzystania obecnej bazy źródłowej (np. Kobyliński, 2015; Gediga, 2017).

\section{JAKI MODEL POZNANIA ARCHEOLOGII HISTORYCZNEJ I CO UZNAJEMY ZA ŹRÓDLA W TYM MODELU?}

Problem leży najpewniej już w samym wyborze teorii oraz modelu poznania. Nawet obecnie w praktyce badań archeologicznych dominuje „obiektywistyczny model poznania" (za: Zybertowicz, 1995), który zakłada dualizm podmiotu i przedmiotu poznania, optymizm poznawczy, założenie o ciągłości rozwoju wiedzy, obiektywizm, empiryzm, ahistoryzm itd. (Rączkowski 2009 [2011], s. 25). Znajdujemy to wszystko w takich koncepcjach badawczych, jak: dyfuzjonizm, ewolucjonizm, archeologia historyczno-kulturowa, funkcjonalizm, procesualizm, strukturalizm, kognitywizm, neodarwinizm itd. Z kolei „konstruktywistyczny model poznania” (za: Zybertowicz, 1995) znajduje się wobec niego w opozycji, ponieważ poddaje pod ocenę samą obiektywność badaczy, a tym samym wszelkie poznanie uznaje za subiektywne, sprawiając wrażenie „postmodernistycznej rewolucji postrzegania archeologii” (Rączkowski, 2009 [2011], s. 25). Konstruktywistyczny model poznania jest jednak obciążony dużą dozą teoretyczności, o czym się zapomina. Dodatkowo już w latach 60. pojawienie się archeologii procesualnej spowodowało pojawienie się „,bardzo perswazyjnej opozycji teoria - praktyka" (Rączkowski, 2009 [2011], s. 23), co już nawet w modelu obiektywistycznym spowodowało podział na praktyków i teoretyków. O ile Nowa Archeologia w opiniach badaczy nie do końca dokonała przełomu, to już modernizm w nauce $i$ archeologia procesualna są prawdziwym kamieniem milowym, ponieważ pozbawiły archeologię „niewinności” (Clarke, 1973), pokazując jej słabości i uproszczenia oraz zamknięcie, gdy tymczasem dyscypliny naukowe zaczynają zacierać swoje granice i tworzyć nową jakość, korzystając nawzajem ze swoich dokonań (Tabaczyński, 2003, s. 239). 
Istniejący również spór naturalistów $\mathrm{z}$ antynaturalistami $\mathrm{w}$ archeologii osadza się tak naprawdę na dyskusji o tym, czy metody nauk przyrodniczych są adekwatne do stosowania w badaniach rzeczywistości pradziejowej. Naturaliści skupiają się na opisie (pozytywizm) i wyjaśnianiu (modernizm), a antynaturaliści podkreślają potrzebę stosowania specyficznych dla humanistyki metod badawczych, objaśniających zjawiska społeczne (Rączkowski, 2009 [2011], s. 27-28).

Gdy zaś dodamy do tego nieustający spór, czy archeologia jest nauką społeczną, czy historyczną, wraz ze wszystkimi słabościami tej polaryzacji, stajemy przed problemem wyboru i uzasadnienia teoretycznych podstaw swojego pisarstwa naukowego. Współcześnie w niektórych kręgach naukowych archeologię można ujmować jako naukę opartą metodologicznie oraz warsztatowo na naukach ścisłych, tym samym można ją klasyfikować jako bliską science (taki był zamysł tzw. Nowej Archeologii). Inni badacze traktują ją jako naukę będącą dziedziną kultury (anglosaskie podejście do archeologii jako antropologii i tzw. etnoarcheologia) lub wręcz jako swoistą literaturę (Johnson, 2013; Hodder, 1995). U schyłku XX w., jak uważa D. Minta-Tworzowska (2000, s. 49), zbiegły się te trzy rozumienia archeologii, a w niej samej mamy do czynienia z przenikaniem się tradycji różnych rodzajów podejść do przeszłości, różnych narracji prahistorycznych. Wszystkie one należą do świata prahistorii, który nie tylko jest światem przeszłym, ale należy też do teraźniejszości. Nie można bowiem zaprzeczyć, że to badacze „obrazują" przeszłość dla sobie współczesnych. I jak uważa Autorka, ta ostatnia teza jest chyba największym „odkryciem” archeologii w końcu XX w.

Problemem jest również podejście do źródeł. Dla archeologów tradycyjnych świat przeszłości jest „odbity” w źródłach i na podstawie tych „skamielin” można obiektywnie zrekonstruować prawdziwy, pewny obraz pradziejów (Marciniak, 2013, s. 18). Z dzisiejszej perspektywy można to nazwać wręcz „oczarowaniem źródłami”, jako informacją obiektywną i bezdyskusyjną (Minta-Tworzowska, 2000, s. 50-51). Dopiero w ramach zwrotu procesualnego i tzw. Nowej Archeologii nawiązano swoisty dialog ze źródłami, zmieniony nieco dzięki późniejszym pracom Iana Hoddera, postulującego, aby przeszłość odkrywaną w źródłach mniej „pisać”, a więcej „,zytać", bo jest ono informacją, którą odczytujemy i hermeneutycznie interpretujemy. Nie możemy przy tym zapominać, że mamy do czynienia z dialogiem czytelnik tekst, gdzie obie strony wprowadzają swoje uwarunkowania i ograniczenia semantyczne w dyskusji (Hodder, 1995, s. 33). Źródła archeologiczne rozumiane są przez archeologów w ramach dwóch modeli, jak uważała Linda Patrik (1985, s. 27 i n.): „fizycznego" (źródło traktowane jak skamielina typu przyrodniczego; określamy jej cechy rodzajowe, gatunkowe itp.) i „tekstualnego" (znaczenie humanistyczne źródeł, zawarte w tradycji, historii i kontekście kulturowym).

Nadal wielu archeologów żywi przekonanie, że źródło archeologiczne pozbawione jest piętna informatora (jako to jest w przypadku źródeł pisanych). Tym samym

\footnotetext{
3 Termin „obrazowanie” wydaje się tu najszerszy, ponieważ zawiera w sobie zarówno przedstawianie obrazu przeszłości (tradycyjne), jak i konstruowanie tego obrazu.
} 
wydaje się bardziej obiektywne i jest wprost pozostałością przeszłej rzeczywistości, a nie tylko „śladem” do odczytania i krytyki w naszym własnym systemie odczytywania informacji, opartym, jak zauważa D. Minta-Tworzowska (2000, s. 53), na naszym stanie wiedzy i przekonaniach badacza kształtowanych kulturowo. Archeolodzy często nie widzą samych siebie i swojego osobistego ,ja” w procesie odczytywania źródeł, tego własnego „piętna informatora”, wierząc we własną obiektywność i umiejętność oderwania się od własnych świadomych i podświadomych przekonań, stosowanych reguł wnioskowania oraz systemu wartości. Nie zauważają, że to oni są „,informatorem” w źródle i to oni przygotowują swoją wersję „informacji źródłowej”. Tymczasem już św. Augustyn zauważał, że żyjemy tylko w teraźniejszości, która ma wiele wymiarów: „teraźniejszość rzeczy minionych, teraźniejszość rzeczy obecnych, teraźniejszość rzeczy przyszłych" (św. Augustyn, 1982, s. 232, ks. XI, 20). Rozróżnienie więc między przeszłością a teraźniejszością jest fundamentem pojmowania czasu. Tym samym nieodzowne jest dla badań historycznych postrzeganie tego faktu jako bezdyskusyjnego i wymuszającego autorefleksję, jeśli chodzi o wszelkie zasady aktualizmu (Le Goff, 2015, s. 41).

Każde wnioskowanie w archeologii wymaga refleksji o związku między naszym modelem wiedzy a budowanym na jej podstawie obrazem przeszłości. Refleksja taka jest niezbędna, ponieważ tylko wtedy uświadamiamy sobie wielość możliwych płaszczyzn badawczych, a dodatkowo jest szansa na właściwy ogląd, zakładający od samego początku subiektywność i brak możliwości stworzenia uniwersalnej dla wszystkich badaczy wizji przeszłości (Rączkowski, 2012, s. 369).

Osobiście uważam, że wiele przemawia za preferowaniem modelu konstruktywistycznego (choć i on jest pewnym uproszczeniem) i podejścia dedukcyjnego, również w narracji archeologicznej, ale nie w sensie zwykłej wynikowości, ale opartego na szerszym i bardziej autorefleksyjnym wnioskowaniu. Tym wnioskowaniem może być wnioskowanie entymematyczne, które podpada pod dedukcję, ale pomija się w nim którąś z przesłanek, najczęściej oczywistą, choć nie zawsze. Arystoteles jednak uznawał je za uprawnione, jeśli użyte pojęcia są jednoznacznie zrozumiałe, a także gdy znana jest całość kontekstu (Arystoteles, 1988, I 2, 1356b). Jak pisze Jerzy Ziomek o podejściu Arystotelesa:

Entymem, czyli wnioskowanie z opuszczoną (przemilczaną) przesłanką, która może być przesłanką oczywistą lub pozornie oczywistą. Takie rozumowanie odwołuje się do wiedzy obiegowej, czyli - inaczej mówiąc - do pewnej wspólnoty wiedzy, ujętej w repertuar gotowych myśli (bądź myśli i obrazów). I to właśnie jest topos, ściślej topos koinós, a po łacinie locus communis, czyli „miejsce wspólne”. (Ziomek, 1900, s. 33)

Ten rodzaj wnioskowania można uznać za stosowany niekiedy w archeologii, na której gruncie przywołuje je np. Jan Michał Burdukiewicz (2012, s. 534). Mamy do czynienia $\mathrm{z}$ wnioskowaniem opartym na uświadomionych lub nieuświadomionych przesłankach, subiektywnie uznanych przez samego badacza. Stan jego wiedzy i przekonania oraz odgórne założenia są ważnym czynnikiem procesu wnioskowania 
i wpływają na jego wynik. O ile jednak w logice uważa się wnioskowanie entymematyczne za obarczone szansą błędu, ponieważ owe „niewypowiedziane przesłanki” mogą być fałszywe i przyjęte bezpodstawnie, a także dlatego że nie podlegają one dyskusji, to bardziej stają się dogmatycznymi założeniami (Ziembiński, 1997, s. 267).

W naukach historycznych refleksja nad sposobami wnioskowania nie zawsze jest wystarczająca. Świadomość stosowania narracji historiograficznej, która jest jednak twórczym obrazem przeszłości, stworzonym w ramach istniejących źródeł i przekonań, już z samej swej istoty jest obarczona marginesem błędu. Nasza więc wiedza o przeszłości nie jest czystym doświadczeniem, ale zapośredniczonymi informacjami, które podlegają subiektywnemu opiniowaniu i modyfikacjom, zależnym od samych badaczy, tworzących te narracje. Jeśli uznać narrację za formę komunikacji, to jest ona według założeń konstruktywizmu ograniczona nie tyle językiem danego badacza, ile językiem całej grupy, do której on należy. Jest więc podporządkowana kodowi kulturowemu, tradycji i przekonaniom, jakie są uznawane przez daną grupę. Tym samym wszelkie komunikaty są tworzone w zakresie wspólnego języka i wspólnych pojęć, a tym samym podlegają wspólnym stereotypom (więcej: Wendland, 2011, s. 64 i n.). Narracja histograficzna staje się więc komunikatem rozumianym wewnątrz subiektywnego systemu pojęć, gdzie każda osoba z danej grupy ma wpływ na zbiorowe rozumienie danej narracji i jednocześnie jest ograniczona wspólnym użytkowanym językiem.

\section{ARCHEOLOGIA A ANTROPOLOGIA KULTUROWA - CZY NALEŻY JE ROZDZIELAĆ?}

Pytanie to jest dość ważne, ponieważ antropologia zajmuje się człowiekiem jako istotą społeczną, kulturową, jego działalnością, a w archeologii tradycyjnej, raczej opisuje się kulturę materialną, a nie samego człowieka z przeszłości. Narracja stawiająca w centrum człowieka, a więc antropologiczna wydaje się pełniejsza niż np. podstawowa dla naszej nauki klasyfikacja przedmiotów.

W systemie nauk obowiązującym np. w Stanach Zjednoczonych, archeologia jest składową nauk społecznych, a na antropologię składają się cztery dziedziny wiedzy (dyscypliny szczegółowe) (Barnard, 2016, s. 27-28): 1. antropologia biologiczna (fizyczna) $)^{4}$, 2. archeologia, 3. językoznawstwo antropologiczne, 4. antropologia kulturowa.

Antropologia kulturowa/społeczna generalnie zajmuje się badaniem społeczności i społeczeństw (czasem stosuje się te terminy jako gradację wielkości) w dwóch aspektach (Barnard, 2016, s. 33-34):

\footnotetext{
${ }^{4}$ Przeżywająca obecnie wielką transformację, ponieważ dzięki rozwojowi nowoczesnych nauk biologicznych, np. genetyki, nie bada się już ras, ale zmiany organiczne w ramach rozwoju i przystosowań ludzi jako całego gatunku (Barnard, 2016, s. 28).
} 
(1) Obserwacją danej społeczności jako całości, a więc badaniem jej elementów składowych jako wzajemnie powiązanych lub znaczących na tle pozostałych, jednak bez oddzielania ich od systemowego kontekstu.

(2) Drugi aspekt to badanie danej społeczności w relacji do innych grup, celem znalezienia istniejących między nimi podobieństw i różnić oraz poszukiwania ich wythumaczenia.

Archeologia w rozumieniu amerykańskim, gdy uznamy ją za dziedzinę antropologii, a nie historiografii, bada ślady struktur społecznych, związki między grupami i konstruuje obraz życia społecznego w przeszłości. Granica między archeologią a antropologią kulturową np. czasów niedawnych nie jest jasno sprecyzowana. Szczególnie że antropologia kulturowa zajmuje się badaniem zróżnicowania kulturowego, poszukiwaniem uniwersaliów kulturowych, ujawnianiem struktur społecznych, interpretacją symboliki i wieloma tematami budzącymi zainteresowanie archeologów. Tym samym zazwyczaj archeolodzy w USA są antropologami kulturowymi (Barnard, 2016, s. 28-30).

A jak wygląda sytuacja w Polsce? W praktyce w naszym kraju nie jest to podejście zbyt szeroko stosowane. Problem ze współpracą i inspirowaniem się nawzajem przez archeologię i antropologię w Polsce zrodził się przez specyficzne po II wojnie światowej ukierunkowanie etnografii (późniejszej etnologii) w kręgu badań przemijającej kultury polskiej wsi, gdzie nie adaptowano zachodnioeuropejskich teorii, starając się wypracować własne. Z kolei polska archeologia w tym czasie, bez wsparcia warsztatu antropologii (jak to było w świecie zachodnim), oparła się na szkole kulturowo-historycznej. Dopiero w latach 80 . XX w.

W Polsce rozpoczęła się dyskusja o wzajemnych związkach archeologii i antropologii oraz możliwościach, jakie dała współpraca teoretyczna tych dyscyplin na gruncie archeologii anglosaskiej. Zaczęto też podważać przestarzałe schematy interpretacyjne i rolę analogii etnograficznych w analizach i interpretacjach archeologicznych (Buchowski, Mamzer, Rozwadowski, Posern-Zieliński, 2012, s. 705). Na gruncie polskim współczesna antropologia to nauka skoncentrowana na bieżącej kulturze i współczesnych społecznościach, idąca „ramię w ramię” z socjologią i kulturoznawstwem. Rzadko kiedy zajmuje się ona przeszłością i wsparciem metodami antropologicznymi archeologii w badaniu przeszłych społeczności (Buchowski, Mamzer, Rozwadowski, Posern-Zieliński, 2012, s. 706).

Wiele elementów nadal je łączy. Antropologia kulturowa, podobnie jak archeologia, ma wizerunek ukształtowany przez tzw. fetysz badań terenowych (Tokarska-Bakir, 2016, s. 11). O ile jednak w kwestii archeologii jest to idea badań wykopaliskowych jako podstawowej aktywności archeologów, to w kwestii antropologii chodzi o to, że dla każdego zjawiska lub instytucji kulturowej można znaleźć analogię u jednego z tysięcy badanych plemion zamieszkujących różne zakątki globu, niekiedy bardzo odległe od siebie. To łączy się szczególnie $\mathrm{z}$ „utowarowieniem wiedzy”, jakie dziś dostrzegamy w nauce. Zazwyczaj jednak mamy do czynienia z nie do końca rzetelnym dostosowywaniem kontekstu do naszego rozumienia zjawiska, ponieważ wszelkie niuanse osłabiłyby ideologiczną moc dowodów oraz argumentów 
(Tokarska-Bakir, 2016, s. 11). Podobne podejście w archeologii dotyczy choćby badań okresów najdawniejszych, gdzie często analogie i wyjaśnienia oparte są na danych z różnych zakątków Europy, a czasem wręcz świata (szczególnie widoczne jest to $w$ badaniach nad epoką kamienia).

Istnieje jednak liczna grupa badaczy, która wprost mówi o potrzebie antropologizacji nauk historiograficznych, w tym archeologii (np. Urbańczyk, 2006, s. 32). Sugerują potrzebę przeprowadzenia podobnego procesu, określanego przez Wojciecha Wrzoska jako ,antropologizowanie” historii, które powoduje m.in. spojrzenie na przeszłość jako na historię społeczeństw, „a nie dzieje państw, dynastii, wybitnych jednostek [...] Aby poznać ją, niezbędne staje się poznanie sfery ekonomiczno-społecznej, sposobów produkcji, wymiany i konsumpcji. [...] np. Marc Bloch traktuje społeczeństwo feudalne tak jak antropolog grupę kulturową" (Wrzosek 1994, s. 168169). Dodatkowo powoduje to daleko idące implikacje, ponieważ badania historii społecznej w powiązaniu z polityczną, włączając $\mathrm{w}$ to aspekt tworzenia kultury materialnej, zbliżają historię antropologiczną do archeologii w ujęciu anglosaskim. Analizując tę kwestię, można uznać, że związek antropologii z archeologią historyczną (kontynentalną) powinien mieć podobne fundamenty, aby kojarzono archeologię z dyscypliną badawczą, opisującą życie społeczne w przeszłości, a nie tylko samą kulturę materialną. Idąc tym tropem, można zadać pytanie, czy archeologia historyczna nie powinna dokonać zwrotu właśnie w kierunku antropologizacji.

Bez łączenia perspektyw: archeologii, antropologii społecznej czy historii trudno byłoby pokazać globalność działań ludzkich w zakresie: sfery ekonomiki, struktury społecznej, działania instytucji, systemu wierzeń, praw, obyczajów, gestów, emocji, a także w takich kwestiach, jak sposób odżywiania, budowy domostw, produkcji przedmiotów codziennego użytku, tworzenia obrzędowości i rytuałów. Ferdynad Braudel, wybitny przedstawiciel szkoły historycznej „Annales”, pisał bowiem o dużej „rutynizacji” życia, gdzie 80-90\% czynności wykonywanych przez ludzi to czynności powtarzalne i wszechobecne, takie jak np. sianie zboża, budowanie domów czy wymiana na towary niedostępne danej grupie, polowanie itd. Nie są to czynności często opisywane w „tradycyjnej historii”, a przecież dotyczą większości ludzi żyjących w przeszłości i zapewne miały olbrzymi wpływ na rozwój całych struktur społecznych. Życia materialnego zasadniczo ,nie da się oddzielić od gospodarki, tak jak wody od oliwy" (Braudel, 1992, s. 24). Twierdził wprost, że cywilizacje są gospodarkami. Cytując Braudela, odnotowujemy: „[...] Każde społeczeństwo, każda cywilizacja jest uzależniona od czynników ekonomicznych, technologicznych, biologicznych i demograficznych. O losie cywilizacji decydują warunki materialne i biologiczne" (Braudel, 2006, s. 52). Choć historyk nie odnosił się bezpośrednio do archeologii, to w swej koncepcji zmusza niejako do śledzenia odkryć archeologicznych jako jedynych mówiących o realiach bytowych społeczeństwa, o mechanizmach związanych z podstawami bytu materialnego, do których dotarcie jest możliwe dzięki źródłom archeologicznym. Tylko dzięki temu można więcej powiedzieć nie tylko o narodach, ale również o jednostkach i mniejszych grupach, które to właśnie składają się na społeczeństwo, a w konsekwencji stanowiły narody (Kajzer, 1994, s. 174). Archeologia 
zyskuje po części status nauki społecznej, nie tylko w sensie badania dawnych społeczności, ale również z powodu jej ścisłego powiązania z obecnie zachodzącymi zjawiskami i procesami społecznymi (Kobyliński, 2009, s. 103-104).

Nie można jednak zignorować tego, że antropologizacja archeologii może stanowić cenny wkład w rozwój warsztatu teoretycznego tej nauki, to należy jednak pamiętać, że archeologia jest dziedziną wiedzy opierająca się na specyficznych źródłach i śladach przeszłości, które są inaczej weryfikowane, niż dzieje się to w przypadku źródeł antropologicznych (szczególnie współczesnych, por. Šmejda, Baumanová, 2015, s. 48).

Archeologia historyczna ma dodatkowy kłopot $\mathrm{z}$ nawiązaniem dialogu $\mathrm{z}$ antropologią. Jak twierdzi Przemysław Urbańczyk, nie da się przejść od „historii archeologicznej” do „historii historycznej” (Urbańczyk, 2006, s. 32), czyli od badania kultury materialnej do badania kultury politycznej bez wiedzy o kulturze społecznej i modelach rozwojowych, jakie stworzyły socjologia i antropologia.

Różni je również sama terminologia. W praktyce badawczej archeologii takie terminy jak społeczeństwo i społeczność używane są dość często wymiennie. Trudno w Polsce o podział podobny do „zantropologizowanej” archeologii anglosaskiej, gdzie społeczność (community) różni się od społeczeństwa (society) poziomem wewnętrznych powiązań i socjalizacji. Przejście zaś od community do society uznawane jest za jeden $\mathrm{z}$ najciekawszych procesów społecznych w przeszłości, kiedy to grupy „komplikowały” wzajemne regulacje i kształtowały zróżnicowane powiązania wewnętrzne. Równocześnie jest to jedno z fundamentalnych zagadnień w antropologii.

W nowoczesnej archeologii rodzi się zarzut o powrocie do ewolucjonistycznego podejścia do stosunków ludzkich, do ich zmiany. Choć odgórnie zakładamy, że wczesne społeczności były słabo skonsolidowane wewnętrznie oraz że w okresach plemiennych i przedpaństwowych możemy mówić o mniej wykształconych wewnętrznych regulacjach $\mathrm{w}$ danej grupie, to jednak trudno jasno pokazać przejście społeczności w społeczeństwo (Šmejda, Baumanová, 2015, s. 52-53).

Perspektywę „antropologizowania” archeologii można jedynie sprowadzić do idei badania procesów społecznych, gospodarczych przez artefakty traktowane „humanistycznie". Podobnie jak to proponuje archeologia kognitywna - należy uznać artefakty za „zdarzenia” (events), czyli jako obdarzone pewną „zmiennością” (czy to np. znaczenia, czy też roli: Neustupný, 2001, s. 34). Problemem jest być może to, że badanie procesów społecznych dotyczących przeszłości wymaga dużej liczby założeń, hipotez i modeli, które obarczone są dozą niepewności, a nawet uproszczeniami. Jednak modele te powinny stać się ważnymi narzędziami w warsztacie badawczym archeologa, wzajemnie się wspierającymi i uwzględnianymi przy tworzeniu narracji.

Podobnie postuluje Urbańczyk, pisząc, że:

nie ma powodu, aby oddzielać tzw. kulturę materialną od kultury pojmowanej całościowo, choć niewątpliwie jest to wygodny sposób uniknięcia trudnych problemów interpretacyjnych [...] Unikanie przejścia do etapu interpretacji antropologicznej skazuje archeologię na marginalizację we współczesnej humanistyce. (Urbańczyk 2006, s. 38) 


\section{„ARCHEOLOGIA HISTORYCZNA” CZY „MEDIEWISTYKA NA BAZIE ŹRÓDEŁ ARCHEOLOGICZNYCH”?}

Badanie okresów historycznych (np. średniowiecza) wymaga bliskiej współpracy obu dziedzin: archeologii i historii, bez zatracenia samodzielności danej nauki. Andrzej Buko stwierdza wręcz, że znakiem dobrej kondycji archeologii wczesnośredniowiecznej są coraz ściślejsze związki z historią (Buko, 2005, s. 28). Również archeologia późnego średniowiecza powinna łączyć swoje analizy i koncepcje z wnioskami opartymi na źródłach pisanych oraz korzystać z modeli zapożyczonych z nauk społecznych, wykorzystywanych w warsztacie mediewistów. Jest to znany postulat, jednak łączenie wyników dwóch nauk nie zawsze jest łatwe i korelacja wniosków bywa przyczyną sporów między ich przedstawicielami. Już jednak w latach 50. XX w. historyk Aleksander Gieysztor współpracował ściśle ze środowiskiem archeologów-mediewistów (Buko, 2005, s. 28), a w latach 70. XX w. część historyków doceniła wyniki badań wykopaliskowych w średniowiecznych miastach i dostrzegła pilną potrzebę uwzględniania ich w przedstawianiu historii rozwoju miast (Rębkowski, 2005, s. 47). Wykopaliska przyniosły bowiem wiele nowych i czasem wręcz rewolucyjnych informacji na temat najstarszych faz grodowych dawnych miast, jednak późniejsze polokacyjne dzieje pozostawały zazwyczaj domeną badań historycznych.

Szczególnie badania milenijne przyczyniły się do rozwoju wiedzy na temat wczesnośredniowiecznych ośrodków miejskich i otworzyły nowe pole dla archeologii średniowiecznej (Leciejewicz, 1991, s. 205). Jednak ugruntowały one podział na „archeologię grodów” i „historię miast”. Jeśli dodamy do tego niepisaną tradycję „archeologii regionów”, w której uznaje się, że „badacz jest przypisany do regionu”, to owocuje to słabszym przepływem informacji i brakiem korelacji wyników badań z różnych ośrodków (Buko, 2005, s. 29). Otrzymujemy obraz dość spetryfikowany, który jednak w ostatnich dziesięcioleciach ulega zmianie. Coraz częściej bowiem prowadzi się badania interdyscyplinarne, co poszerza recepcję wyników badań z obu nauk. Współczesna mediewistyka staje się na naszych oczach konglomeratem nauk, gdzie wzajemne uzupełniają się archeologia i historia oraz wprowadzane są teoretyczne modele antropologiczne.

Udział badań archeologicznych w szeroko pojętej mediewistyce jest jednak obarczony pewną niedogodnością. Archeologia średniowiecza jest bowiem w trudnej sytuacji o tyle, o ile musi konfrontować swoje odkrycia z dotychczasowymi koncepcjami historyków, stwarzając wrażenie badania kwestii już znanych i dawno już określonych na bazie źródeł pisanych (Rębkowski, 2008, s. 13). Jednak często dane pozyskane przez archeologów zmieniają obraz średniowiecza albo wręcz pokazują inny kontekst, który nigdy nie był wspominany przez historyków-mediewistów. Większość spośród nich korzysta niemal wyłącznie ze źródeł pisanych, których przyrost jest znikomy, w przeciwieństwie do kolejnych odkryć archeologicznych. Problemem jest też odmienny sposób formułowania wniosków, odmienna terminologia obu nauk, co tworzy nieporozumienia (Kurnatowska, 2012, s. 9). Na szczęście fakty te skłaniają, w opinii wielu badaczy, do postulowania potrzeby ponownego i bardziej 
merytorycznego uwzględniania źródeł archeologicznych przez mediewistykę i bardziej refleksyjnego korzystania z nich $\mathrm{w}$ celu rozpoznania stylu oraz charakterystyki życia codziennego, rozplanowania siedzib, a nawet badania handlu, procesów gospodarczych i kulturowych (choć tutaj historycy zakładają większy margines błędu w interpretacji danych pozyskanych przez archeologów, np. Suchodolski, 2008, s. 7).

Sami archeolodzy mają jednak problem z oceną archeologii historycznej, łączenia jej dokonań $\mathrm{z}$ innymi naukami. Jest tu również wiele naleciałości związanych z dawnymi sporami z historykami. I tak na przykład Stanisław Tabaczyński uznaje archeologię średniowieczną za dział zajmujący się okresem postplemiennym, ale nie nakreśla jasno różnic warsztatowych pomiędzy nią a archeologią pozostałych epok (Tabaczyński, 1987, s. 43). Uważa jednak, że ilość źródeł dla tego okresu jest szersza i musi obejmować również źródła pisane. Archeologia średniowieczna powinna być traktowana jako nauka formalnie od historii oddzielona, ale $\mathrm{z}$ tą ostatnią połączona przedmiotem badań (Tabaczyński, 1987, s. 9 i n.). Archeologia, choć już dawno przestała być nauką pomocniczą historii i stała się samodzielną, to jednak wciąż jest traktowana jako jedna $\mathrm{z}$,młodszych” dziedzin nauk historycznych, dopiero tworzących swoją metodologię (Rębkowski, 2008, s. 28). W związku z tym niektórzy historycy w sposób wybiórczy wykorzystują dane pozyskane przez archeologów.

Powyższe antagonizmy zauważał już pod koniec lat 80 . XX w. choćby Jacques Le Goff, który miał problem z określeniem archeologii, czy jest ona nauką pomocniczą historii, czy też osobną dziedziną, ponieważ dostrzegał, że sama archeologia ewoluuje w kierunku historii kultury materialnej w rozumieniu całościowym, a więc staje się częścią historii, a jej dobór źródeł przestał ją od niej jasno separować. Nowoczesna archeologia, według niego, korzysta ze źródeł pisanych, z dokumentów i wielu ewidentnie „niewykopaliskowych” źródeł. Dyskusja ta jest wciąż aktualna. Korzystanie ze źródeł innych niż pozyskanych tradycyjnie podczas wykopalisk oraz opracowanie tak odkrytych artefaktów stało się jeszcze szersze. Tym samym powstaje pytanie, czy nie mamy do czynienia z powrotem archeologii do bycia historią, a tym samym dyskusja o jej pozycji w ramach systemu nauk staje się bezzasadna (Le Goff, 2015, s. 255). Moim zdaniem ocena ta, rozumiana dosłownie, tylko pozornie sugeruje powrót do „służebności nauki względem historii”. Jest raczej oceną zmian, jakie zachodzą w samej archeologii i źródłach przez nią wykorzystywanych. Archeologia nigdy nie przestała być nauką historyczną w powyższym sensie. Raczej mamy do czynienia z pytaniem o interdyscyplinarność i szerokie wykorzystanie różnorodnych źródeł w badaniach historycznych. Zbyt dogmatyczne podejście do specyfiki źródeł z jednej strony „archeologicznych”, a z drugiej „historycznych” wydaje się problemem źle postawionym. Dlatego dyskusja o związkach archeologii z historią w XXI w. jest niezbędna. Ta potrzeba rodzi się również z tego powodu, że w ostatnich latach mocno rozwinęła się nowoczesna historiografia, co powinno zostać również zauważone $\mathrm{w}$ archeologii. Obecna historiografia optuje za koncepcją ciągłości w procesie historycznym, ale dopuszcza dyskontynuację i alternatywną ścieżkę rozwoju, tym samym zastępując idee rewolucji jako nieciągłości (Wrzosek, 2010, s. 62). Jest to podejście bardziej refleksyjne i mniej uwikłane ideologicznie niż typowe 
rozumienie rewolucji jako momentów „dramatycznego przerwania” procesu dziejowego. Odchodzi również od punktowości chronologicznej na rzecz określania czasu trwania zjawisk i zdarzeń. Już nie konkretna data, ale okres staje się podstawową jednostką opisową procesu dziejowego (Wrzosek, 2010, s. 125). Historiografia scjentystyczna (modernistyczna) stosuje również poznanie człowieka z poziomu ogólnego, traktując go jako część społeczności i społeczeństwa. Tym samym uznaje, że poznanie historii istoty ludzkiej jest możliwe przez badanie dziejów społecznych, grup ludzkich oraz zjawisk i procesów im towarzyszących (tj. gospodarka, cywilizacja, zmiany społeczne: Wrzosek, 2010, s. 134). Jest również bardziej autorefleksyjna, ponieważ nawołuje do ciągłego aktualizowania swoich wniosków. Przywoływany już Jacques Le Goff mówi wprost o postrzeganiu badań historycznych i historiografii jako o „ciągu nowych odczytań przeszłości, pełnych strat, ale i ponownych objawień, dziur w pamięci i kolejnych rewizji" (Le Goff, 2015, s. 170). Uznaje on proces badawczy za nieustające „uaktualnianie” naszej wiedzy na temat przeszłości (Le Goff, 2015, s. 170).

Następnym problemem związanym ze współpracą archeologii i historii w odniesieniu do średniowiecza jest również kwestia uporczywego traktowania źródeł pisanych jako bardziej wiarygodnych niż źródła archeologiczne, uznając te ostatnie za bardziej podatne na błędy interpretacyjne niż słowo pisane. Taka hierarchizacja, zdaniem niektórych historyków często lekceważy źródła archeologiczne i staje się wręcz oznaką dogmatyzmu (Domańska, Urbańczyk, 2012, s. 857-860). Nie ustrzegł się wybitny metodolog historii Jerzy Topolski, który uważał, że archeolodzy są w gorszej sytuacji niż historycy, ponieważ specyfika źródeł jest odmienna. Historycy, korzystając ze źródeł pisanych, interpretują dane źródłowe pozyskane z zapisów, czyli mają pośrednika w postaci „,rzeczywistego informatora”, a archeolodzy nie mają takiej sytuacji. Muszą informacje wydobyć ze źródeł materialnych (gdzie nie mamy danych od twórcy, „,czym jest dany obiekt” itp.). Archeolog konstruuje więc obraz przeszłości na bazie faktów, tworzonych danych i przesłanek uzyskanych dzięki tekstualizacji źródeł i kontekstów archeologicznych. Nie oznacza to, że na historyków nie czekają pułapki w postaci życzeniowych interpretacji źródeł pisanych czy fałszywych treści zawartych w tych źródłach (np. Topolski, 1973; 2000, s. 70-72; 2008, s. 284 i n.; 2016, 101 i n.).

Dodatkowo widoczny jest, choć rzadko podnoszony wpływ wzajemnego traktowania się archeologów i historyków. To spotykane czasem sugerowanie indolencji historyków wobec źródeł archeologicznych i archeologów wobec słowa pisanego tworzy często wrażenie uników, kiedy to zamiast rzeczowej dyskusji nad wspólnym problemem, każda dziedzina ,usztywnia” swoje stanowisko, bez szukania kompromisu (Domańska, Urbańczyk, 2012, s. 865). Archeologia i historia tylko pozornie wydają się naukami, które powinny bezproblemowo współpracować, ponieważ przedmiot ich badań wydaje się podobny. Obie te dyscypliny zajmują się życiem ludzi w przeszłości, jednak, jak uważa Urbańczyk (2014, s. 255), proces stopniowej specjalizacji operacji przeprowadzanych na ,wydobywaniu z ziemi” świadectw materialnych oraz na „zdejmowanych z półki” źródłach werbalnych systematycznie oddalał od siebie obie te nauki. Typowy zaś dla archeologii sposób opisu oparty na analizie choćby 
warstw stratygraficznych czy przedstawianiu wyników typologii jest bardzo trudny do wykorzystania dla historyków, przyzwyczajonych do narracji zawierającej motywacje, oceny postaw, analizy polityczne i emocjonalne opinie. Ta zaś tworzona w archeologii dotyka lokalności i rzadko kiedy opowiada o konkretnych ludziach albo zjawiskach w szerszej skali niż dany region. Nie jest to też narracja opisująca wydarzenia historyczne w sposób przyjęty przez historiografię, gdzie ważna jest data (zazwyczaj roczna), a nie ogólne, ramowe datowanie źródła (Urbańczyk 2014, s. 259). Archeolodzy rozumują w stylu: „Jak coś jest dawne?”, a historycy „Jak dawno dane wydarzenie miało miejsce?”. Problem można ująć jako rozbieżność miedzy „ramowym datowaniem” a „określaniem konkretnej daty”. Zazwyczaj rzeczywiście spór dotyczy odczytywania i pozyskiwania źródeł, gdzie każda nauka, jako lepiej przygotowana do oceny „swoich” źródeł, przedkłada je nad inne, a możliwe braki warsztatowe są lekceważone.

Przykładem dla mnie jest choćby kwestia definicji miasta, z którym w opinii wielu historyków mamy do czynienia, jeśli nadano prawa miejskie i zaistniał akt lokacji miasta, a w ramach archeologii opiera się ona często na ocenie funkcji danego ośrodka i ma charakter uznaniowy. Kluczową kwestią w tych rozstrzygnięciach jest doba przedlokacyjna $\mathrm{w}$ funkcjonowaniu danego ośrodka, słabo rozważana przez historyków. Można to uznać za lekceważenie faktów i źródeł (również pisanych, np. relacje podróżników) dokumentujących liczne funkcje typowo miejskie danego ośrodka, gdzie akt lokacji jest tylko ich potwierdzeniem, a nie zmianą jakościową danego grodu i przekształceniem go w miasto.

Kwestię zaś interdyscyplinarności badań łączących źródła i metody badań historycznych i archeologicznych adekwatnie oddał Jerzy Strzelczyk, uznając, że lepiej wyjść od „celu” badań i ukierunkowując się na niego, badać określone źródła, a nie na bazie źródeł dochodzić do celów i dopiero wtedy łączyć dane archeologiczne z historycznymi. To drugie podejście owocuje często sporami między badaczami reprezentującymi odmienne nauki, ponieważ cele badawcze, jakie osiągnęli na bazie „swoich” źródeł, często są trudne do porównania ze sobą z powodu licznych różnic metodycznych w podejściu do nich (Strzelczyk, 2012, s. 25). Znaczenie ma obawa przed konfrontacją wniosków obu nauk. Zdaje się panować niepisana reguła, aby rozgraniczać badanie przeszłości na okresy „oświetlone” przez źródła pisane, w badaniu których prymat mają historycy, i „nieoświetlone”, gdzie mogą się wypowiadać archeolodzy (Brzostowicz, 2012, s. 43-44). Owocuje to często uproszczeniami i merytorycznym osłabieniem wagi odkryć zarówno historycznych, jak i archeologicznych. Elżbieta Kowalczyk-Heyman jasno dodaje, że podstawowy problem w łączeniu dorobku archeologii średniowiecznej z historią leży w niezrozumieniu ograniczeń obu nauk u badaczy oraz braku umiejętności merytorycznego oraz krytycznego włączania osiągnięć obu dziedzin w tok wnioskowania badawczego (Kowalczyk-Heyman, 2012, s. 35). Zauważa również, że specyfika zawodu archeologa, często skoncentrowana na badaniach komercyjnych i ratowniczych, osłabia jego rolę jako badacza przeszłości, tym samym utrudnia weryfikację jakości warsztatu badawczego poszczególnych osób, jak to ma miejsce w historii, gdzie 
nacisk na merytoryczne walory pracy naukowej i publikowanie wniosków oraz syntez jest wyższy (Kowalczyk-Heyman, 2012, s. 28).

Pogodzeniem tych sporów kompetencyjnych między historią i archeologią byłoby uznanie, za Danuta Mintą-Tworzowską, że archeologia jest jednocześnie antropologią i historią (Minta-Tworzowska, 2012, s. 117). To połączenie powoduje, że może ona łączyć typowo antropologiczne badanie źródeł „niemych” i przejawów życia codziennego z przeszłości z wykorzystaniem koncepcji historycznych. Jest więc to nauka bardziej generalizująca niż historia i więcej w niej cech nauki społecznej niż w badaniach historycznych. Tym samym archeolog łatwiej może łączyć swoje wnioski z wiedzą historiograficzną, niż historykowi wykorzystywać specyfikę obrazu przeszłości konstruowanego przez archeologa. Nie do końca zgadza się z tym Henryk Mamzer, uznając za I. Hodderem, że „,archeologia jest archeologią” (Hodder, 1995, s. 225), czyli osobną nauką, korzystającą wprawdzie z narzędzi z innych nauk, $z$ ich warsztatu pojęciowego, ale ma własne metody wnioskowania i interpretowania. Postuluje, aby sposobem komunikowania się z innymi naukami był wspólny metajęzyk na gruncie humanistyki zintegrowanej (Mamzer, 2012, s. 238). To podejście jest mi bliższe, choć koncepcja Danuty Minty-Tworzowskiej de facto lepiej oddaje praktyczne podejście do możliwości poznawczych archeologii. Tym samym uznaje, że archeologia jest archeologią, ale w swym funkcjonowaniu powinna szeroko korzystać z koncepcji historycznych i antropologicznych, ponieważ tylko tak uzyskujemy fundamenty teoretyczne do tworzenia obrazu przeszłości na użytek społeczeństwa.

Dążenie do łączenia wniosków dotyczących historii średniowiecza $\mathrm{z}$ archeologią średniowiecza, do realizacji idei transdyscyplinarności i interdyscyplinarności nie powinno być dogmatyczne, ale bardziej należy podjąć próbę tworzenia wspólnoty zrozumiałych pojęć dla obu nauk. Przestrogą powinny być słowa Zbigniewa Kobylińskiego, który korzystanie z niektórych metod zapożyczonych z innych nauk uznaje często za niefrasobliwe. Podejmuje się bowiem próby zastosowania danej metody „do wszystkiego". Brakuje natomiast autorefleksyjnego pytania o zasadność jej użycia, również merytorycznej analizy i krytyki danej metody przed przystąpieniem do jej aplikacji we wnioskowaniu (Kobyliński, 2012, s. 360). Te wszystkie zagadnienia powinny być obecne w narracji dotyczącej minionego świata.

\section{NARRACJA HISTORYCZNA CZY ARCHEOLOGICZNA?}

Powyższe pytanie nie jest bezpodstawne, ponieważ widoczne są duże różnice w praktyce badawczej, co przekłada się na styl pisania tekstów naukowych. Przeszłość, a dokładnie jej obraz, na dobrą sprawę jest wytworem teraźniejszości, ponieważ jest kształtowana według potrzeb (i możliwości) naszych czasów. Znaczenie obrazowi dawnych czasów nadają współcześni badacze, którzy waloryzują przeszłość jako przeszłość społeczną (Marciniak, Minta-Tworzowska, Pawleta, 2011, s. 10). Wymaga to pogłębionej refleksji nad samą narracją. Struktura narracji historycznej według Jerzego Topolskiego (2008, s. 288) składa się z trzech warstw i tak podchodzą 
do tego historycy, a archeolodzy rzadko kiedy dokonują podobnej refleksji nad swoim przekazem: (a) warstwy informacyjnej - informacja o przeszłości; (b) warstwy perswazyjnej (retorycznej) - zabiegi uwiarygodniające i uzasadniające taki, a nie inny wybór argumentów i elementów informacyjnych; (c) warstwy ideologiczno-teoretyczno-sterującej całą narracją i selekcją informacji.

Jerzy Topolski uważał, że historyk nie ma dostępu do przeszłej rzeczywistości, a źródła nie mają charakteru „lustrzanego”, czyli nie odbijają przeszłości. Uznawał, że ów „kontakt” między przeszłością a narracją historyczną zapewniają źródła jako swoiste „nici” łączące nas z badanym okresem. Ta metafora najlepiej oddaje możliwości historiografii (Topolski, 2008, s. 321). Dodatkowo Topolski postulował, że „,ideologia jest zanurzona w społeczeństwie i rozwija się wraz z jego rytmem" (Topolski, 2008, s. 307). Historiografię uważał za mitotwórczą. Mity mają różne źródła: psychologię twórczości naukowej, ideologię, manipulację i cenzurę. O ile trzy ostatnie łatwo wyjaśnić, to psychologiczne źródła mitów zazwyczaj nie są dyskutowane, ponieważ dotyczą po prostu przywiązania badaczy do swoich własnych poglądów i niechęci do ich weryfikacji. Wynika to $\mathrm{z}$ ludzkiej natury i przekonań, nie ma w tym nic wstydliwego, o ile jest związane z krytyczną autorefleksją (Topolski, 2008, s. 222). Z kolei Wojciech Wrzosek zwraca uwagę na to, że historiografia wywodzi się z literatury, a dokładnie z kronikarstwa.

Archeologia pozytywistyczna skierowała się w kierunku nauki quasi-przyrodoznawczej, jednak na skutek specyfiki swoich źródeł, braku kontaktu z „żywą” kulturą, nigdy nie osiągnęła typowej dla nauk przyrodniczych weryfikowalności empirycznej i jak każda nauka humanistyczna wnioskuje na podstawie prawidłowości, a nie praw. Tym samym jej ciągły kryzys tożsamości wynika właśnie z tego zawieszenia między nauką historiograficzną (a więc humanistyczną) a nauką w sensie science (Wrzosek, 2010, s. 19-21).

Dochodzi do tego problem podejścia „platońskiego”, zakładającego swoistą

przezroczystość świata i dostępność prawdy, [...] i taktykę poznawania, z natury swej rzekomo nieuchronnie prowadzącą do prawdy [...] Krytyka postmodernistyczna dowiodła jednak, że historiografia musi przyznać się do podejścia arystotelesowskiego [akcentującego założenie, że] „świat przesłonięty jest kulturą, bądź istnieje tylko w niej samej. (Wrzosek, 2010: 21)

Te same uwagi można odnieść do archeologii historycznej w jej kanonicznej postaci, gdzie również pojawia się mniej lub bardziej świadome podejście uznające nasze wnioski dotyczące przeszłości za „oparte” na źródłach, a nie „odczytane” w ramach naszej wiedzy i kontekstu kulturowego.

Kwestię różnic w postrzeganiu pisarstwa archeologicznego i historycznego można sprowadzić do opinii, że historycy analizują teksty i piszą kolejny tekst, a archeolodzy zaczynają od obiektów materialnych i na ich bazie piszą teksty (Lesure, 2015, s. 58). To uproszczenie jest dobrym punktem wyjścia do dyskusji, czy zasadne jest usilne odróżnianie narracji historycznej od narracji archeologicznej. Dostrzegamy 
podobieństwa tych dwóch narracji, idąc tropem Haydena White’a, który uważa, że w naukach historycznych spotykamy się z klasyczną narracją (White, 2009), w której mamy do czynienia ze wstępem, rozwinięciem i zakończeniem oraz widocznym ciągiem wydarzeń (argumentów, wniosków cząstkowych itd.) w dążeniu do końcowych wniosków. W archeologii wprawdzie mamy zazwyczaj do czynienia z metanarracją, narracją odgórną lub zideologizowaną. W pracach archeologicznych widoczny jest bowiem nacisk na przedstawienie obrazu przeszłości, wspartego i uargumentowanego pozostałościami materialnymi albo mniej lub bardziej uświadomionego pokazania, jak źródła archeologiczne są wykorzystywane do stworzenia teraźniejszych przekonań (Lesure, 2015, s. 60). Oczywiście trudno w tradycyjnie pojmowanej archeologii o narzucenie struktury wstęp, rozwinięcie, zakończenie, w takim ujęciu, jak jest wykorzystywane do opisu tzw. procesów dziejowych (geneza zjawiska, proces i działania ludzkie, ocena). Dostrzeżenie jednak „statyczności obrazu” w narracji archeologicznej jest niezbędne, ponieważ tylko wtedy widzimy, że najbardziej wnikliwa klasyfikacja elementów z „obrazu” nie może zastąpić oceny i krytyki zarejestrowanych elementów danego momentu z przeszłości.

Trzeba też pamiętać, jak ujmował J. Topolski, że archeolodzy korzystają ze źródeł nieadresowanych, które nie są perswazyjne, ale mogą mieć mniej lub bardziej wyraźnie zarysowaną warstwę ideologiczno-teoretyczną (np. sens wytworzenia danego przedmiotu czy danego stanu rzeczy), a które włączone do narracji historycznej od razu stają się elementem perswazji (Topolski, 2008, s. 288-289).

Tymczasem archeolog Zbigniew Kobyliński uważa, że trzeba uznać „,archeologię za formę działalności społecznej mającej ścisły związek z aktualną rzeczywistością" (Kobyliński, 2003, s. 224). Archeologia jest uprawiana tu i teraz przez badaczy żyjących obecnie. Nakłada to na archeologów wymóg dostrzeżenia swojej roli i podjęcia się jej pełnienia otwarcie, wnosząc swój wkład w rozwój naszej wiedzy o przeszłości.

Archeologia (tak samo jak historia) ma swój wkład w tworzenie mitów narodowych, które nierzadko prowadziły do utrwalania poglądów nacjonalistycznych i szowinistycznych (Kobyliński, 2003, s. 225), a dodatkowo nierzadko pomijała krytykę anachronicznych koncepcji, np. uzasadniania za wszelka cenę i obronę granic politycznych, bez refleksji o ich zmienności historycznej. Tym samym często tworzyła zafałszowany obraz przeszłej rzeczywistości, odwołując się do migracji, dyfuzji w odniesieniu do różnych społeczności, co nie było uprawnione.

Narracja archeologiczna dodatkowo jest „maksymalizowana opisowo” w takim sensie, że powstaje obszerna monografia mająca na celu wieloaspektowe przedstawienie wyników wieloletnich badań, wielu autorów i z bardzo szeroką gamą tematów powiązanych często jedynie lokalizacją. Na skutek tej „maksymalizacji” przedstawienia monografie stają się często tzw. zbiorami artykułów tworzących wielowątkową narrację na temat danego miejsca, gdzie nie ma nacisku na spójność przedstawionych elementów obrazu przeszłości. Widoczne są za to narzędzia perswazyjne stosowane w odbiorze danej pracy. Przykładem może być obowiązkowy element rozpoczynający większość prac; jest nim zazwyczaj historia badań, często obejmująca dekady czy wręcz stulecia, która już od początku perswazyjnie przedstawia ogrom wykonanej 
pracy, aby czytelnik dostrzegł „wielkość” dzieła. Niestety zazwyczaj wnioski rzadko są czymś więcej niż tylko prostym podsumowaniem wyników badań.

Przykładem dopracowanej merytorycznie dokumentacji badań i analiz materiałowych są pozycje z serii Origines Polonorum. Kilkusetstronicowe monografie poświęcone najważniejszym ośrodkom wczesnośredniowiecznym na ziemiach polskich są bardzo dobrym podsumowaniem badań. Niestety większość wniosków merytorycznych, interpretacyjnych, pokazujących historyczny rozwój danego ośrodka, zawiera się na kilkunastu stronach i rzadko wsparta jest analizą porównawczą z innymi ośrodkami lub poszerzoną krytyką na tle regionu lub choćby własnego zaplecza. Taką sytuację znajdujemy choćby w publikacji: Szczecin Wczesnośredniowieczny. Nadodrzańskie centrum (Kowalska, Dworaczyk, 2011); Wolin Wczesnośredniowieczny (Stanisławski, Filipowiak, 2013, 2014) i inne z tej serii. To sprawia, że skrupulatne analizy archeologiczne nie służą próbom „swoistego” wpisania danego ośrodka w szersze tło dziejowe. Nie zawierają bardziej wnikliwej analizy rozwoju społecznego i próby zgeneralizowanego przedstawienia zmian społecznych w tych ośrodkach. Nie znajdujemy tu analiz antropologicznych ukazujących kondycję zdrowotną ludzi tu żyjących. W opracowaniu Wolina znalazł się rozdział o chrystianizacji, ale jest to podsumowanie źródeł i nie ma on aspiracji do przedstawienia tych zmian w szerszej perspektywie, co sugerują tytuły rozdziałów ${ }^{5}$.

Problemem jest również kwestia szerszej interpretacji i tworzenia całościowego obrazu warunków życia we wczesnym średniowieczu. Nie chodzi o tworzenie „wielkiej narracji”, ale o sformułowanie wniosków łączących poszczególne analizy. Takich, żeby np. opis kultury materialnej był podstawą do analiz kontaktów i zmian w społeczności, a nie tylko podsumowaniem wykopalisk, gdzie każdy badacz-specjalista opisał materiał, którym dysponował i na tym poprzestano.

Taką tendencję do tworzenia „wielkich” monografii (lecz czy narracji?), choć „rozbitych” wewnętrznie, mimo że „obszernych” obserwujemy coraz częściej. Powstają wielowątkowe narracje obrazujące ogrom źródeł przy zmniejszającej się liczbie interpretacji, często jednoaspektowych (Lesure, 2015, s. 66-72).

Tradycyjnym monografiom archeologicznym bliżej jest do narracji realistycznej z XIX w. Duży nacisk położony był w nich na przedstawianie codzienności i rzeczywistości w jej „Zwyczajności”. Dlatego analizuje się wszystkie opisane artefakty i inne przedmioty - przedstawia się obraz całościowy materialnej sfery „życia” codziennego, do którego ma prowadzić typologia, a nie analiza funkcjonalna i próby odpowiedzi na pytania o tzw. kulturę żywą. Towarzyszy temu staranie, aby jak najszerzej oddać ich rzeczywiste trwanie i funkcjonowanie, celem uzyskania realistycznego obrazu (Soli, 2015, s. 77). Patrząc na sposób tworzenia narracji archeologicznej, gdzie przedstawiane są wyniki badań i szczegółowych analiz dotyczących np. danego

\footnotetext{
${ }^{5}$ Są też przykłady pozytywne, gdzie znajdujemy poza analizami archeologicznymi, również antropologiczne, historyczne i próbę odpowiedzi na temat rzeczywistego funkcjonowania danego obszaru i oceny stanowiska jako zespołu całościowego. Można to znaleźć choćby w: Bodzia. A Late Viking- Age Elite Cementary in Central Poland (Buko, 2015). Takie prace są jednak rzadkością.
} 
stanowiska, można się zastanowić, czy jest to nieuświadomione nawiązywanie do klasycznych koncepcji narracyjnych, w których badacz przypomina „zecera”, który z ,literek-faktów” układa swoje wnioski, dobierając je odpowiednio, aby potwierdzić lub obalić jakąś tezę (Topolski, 2008, s. 21). Podobnie archeolog tworzy komunikat w „swoim” języku z wyników podjętych badań (artefaktów, śladów osadnictwa, analiz itd.), ujętych w kontekście posiadanego i uznawanego przez siebie stanu wiedzy.

\section{WNIOSKI}

Celem niniejszego artykułu jest poddanie pod dyskusję potrzeby dotyczącej większej autorefleksji u badaczy zajmujących się archeologią średniowieczną. Czego powinna ona dotyczyć? Mniej lub bardziej uświadamianego przez badacza wpływu bagażu subiektywnych przekonań oraz przyjmowanych poglądów na temat warsztatu archeologii historycznej, mających wpływ na wysuwane wnioski i interpretacje zawarte w narracji.

Gdy w narracji używamy frazy „w świetle archeologii...”, to nie traktujemy jej jako słowa-wytrychu czy zwykłej metafory. Odwołujemy się do bogatej tradycji badawczej, przyjmując, że wiedza z tego zakresu nie wymaga dodatkowych objaśnień. Dlatego użycie powyższego stwierdzenia wymaga od badacza największego zdyscyplinowania, ponieważ oznacza ono przyjmowane przesłanki metodologiczne, na bazie których dokonujemy dalszych analiz. Można je sprowadzić do tezy: „w świetle wybranego przeze mnie sposobu pojmowania i uprawiania archeologii”. W takim stwierdzeniu mieści się konieczność określenia podejścia badacza do sposobu budowania obrazu przeszłej rzeczywistości. Musimy przyjąć określoną perspektywę: czy obraz ten jest konstruowany, czy może rekonstruowany, odczytywany niejako wprost ze źródeł i różnorodnych analogii. To drugie podejście daje przesłanki, aby w pytaniach dotyczących choćby życia codziennego, uznać badane źródła za wiarygodne, a tym samym jako obiektywnie ukazujące podstawy egzystencji (np. skład diety w przeszłości). Jednak należy mieć świadomość, że interpretacja jest wszechobecna - nawet na poziomie opisu ,rutynowych” czynności i wytworów, a zwłaszcza w odniesieniu do symboliki i elementów związanych z kulturą i stylem życia. Dlatego powstające w pracach naukowych obrazy przeszłości są raczej jej konstrukcją niż rekonstrukcją.

Kolejną sprawą jest pytanie o to, czy nasze badanie dotyczy poziomu wytworów i relacji twórca - rzecz - użytkownik, czy może badamy zjawiska na poziomie społeczności ludzkich, uznając ich wytwory za przesłanki do budowania całościowego obrazu, gdzie artefakty stają się swoistym medium poznawczym, a nie przedmiotem samego badania. Odpowiedź na to pytanie zmusza nas do wykorzystywania metod nauk antropologicznych i koncepcji wypracowanych przez antropologię kulturową na gruncie archeologii historycznej.

Ważnym elementem i ukierunkowaniem każdej narracji jest cel, jaki sobie stawiamy i co chcemy osiągnąć oraz czy nasze badania są komentarzem do zastanego stanu badań, nawiązaniem czy rozwinięciem, a może krytyką. 
Należy również określić swoje podejście do charakteru archeologii historycznej. Można założyć, że archeologia jest w dużym stopniu nauką historyczną, ale nie jest historią. Podobnie historia nie może być archeologią. Różni je podejście do źródeł, praktyka badawcza i metodyka badań. Tak przynajmniej można sądzić, patrząc na tradycyjne podejście do badań i sposoby przedstawiania obrazu przeszłości. Historia jest bardziej „literacka”, a mniej kategoryzująca, a więc nie tworzy dużej ilości wykresów, tabel i klasyfikacji. Nie chodzi mi o wrażenie, że historia jest bardziej „atrakcyjna” niż archeologia, która kojarzy z „zastygłym obrazem”, a nie procesem dziejowym, jak dzieje się to w historii. Rozbudowana kategoryzacja i aparat klasyfikacyjny archeologii nie zwalnia jej z konieczności formułowania jasnych tez czy przedstawiania wyczerpujących wniosków. Historycy poddają ocenie swoje źródła, archeolodzy czynią to rzadziej.

Niniejszy tekst w zamyśle ma stanowić komentarz do zastanego stanu wiedzy i ma być próbą zwrócenia uwagi na potrzebę bardziej świadomego podejścia do podstaw własnego warsztatu naukowego. Fraza „W świetle archeologii...” posłużyła powyższym rozważaniom.

\section{BIBLIOGRAFIA}

Arystoteles

1988 Retoryka-Poetyka. Warszawa: PWN.

Św. Augustyn

1982 Wyznania (Z. Kubiak, thum). Warszawa: PAX.

Barnard, A.

2016 Antropologia. Zarys teorii i historii. Warszawa: PIW.

Braudel, F.

1992 Kultura materialna, gospodarka i kapitalizm, XV-XVIII wiek, t. 1-3. Warszawa: PIW.

2006 Gramatyka cywilizacji. Warszawa: Oficyna Naukowa.

Brzostowicz, M.

2012 Archeologia i historia - nieporozumienia, niepokoje, nadzieje. W: M. Brzostowicz, M. Przybyła, D. A. Sikorski (red.), Archaeologia versus historiam - historia versus archaeologiam. Czyli jak wspólnie poznawać średniowiecze (s. 40-48). Poznań: PTPN.

Buchowski, M., Mamzer, H., Rozwadowski, A., Posern-Zieliński, A.

2012 Antropologia a archeologia. W: S. Tabaczyński, A. Marciniak, D. Cyngot, A. Zalewska (red.), Przeszłość społeczna. Próba konceptualizacji (s. 686-720). Poznań: Wydawnictwo Poznańskie.

Buko, A.

2005 Archeologia Polski wczesnośredniowiecznej. Odkrycia - Hipotezy - Interpretacje. Warszawa: Trio.

Buko, A. (red.)

2015 Bodzia. A Late Viking - Age Elite Cementary in Central Poland. Leiden - Boston: Brill. Burdukiewicz, J. M.

2012 Rozumowanie. W: S. Tabaczyński, A. Marciniak, D. Cyngot, A. Zalewska (red.), Przeszłość społeczna. Próba konceptualizacji (s. 531-541). Poznań: Wydawnictwo Poznańskie.

Clarke, D.

1973 Archaeology: The loss of innocence. Antiquity, 47(185), 6-18. 
Domańska, E., Stobiecki, R., Wiślicz, T.

2014 Wprowadzenie. W: E. Domańska, R. Stobiecki, T. Wiślicz (red.), Historia - Dziś. Teoretyczne problemy wiedzy o przeszłości (s. 7-16). Kraków: Universitas.

Domańska, E., Urbańczyk, P.

2012 Archeologia i historia. W: S. Tabaczyński, A. Marciniak, D. Cyngot, A. Zalewska (red.), Przeszłość spoteczna. Próba konceptualizacji (s. 852-868). Poznań: Wydawnictwo Poznańskie.

Gediga, B.

2017 Doświadczenia metodyczne i metodologiczne badań milenijnych oraz ich rola społeczna. Przegląd Archeologiczny, 65, 35-44.

Grążawski, K.

2014 Funkcje militarne grodów monarchii wczesnopiastowskiej na północnych rubieżach państwa. W: K. Chrzan, K. Czapla, S. Moździoch (red.), Funkcje grodów w państwach wczesnośredniowiecznej Europy Środkowej. Spoleczeństwo, gospodarka, ideologia (s. 61-71). Wrocław - Głogów: IAE PAN.

Harris, E. C.

1989 Zasady stratygrafii archeologicznej. Warszawa: Biblioteka Muzealnictwa i Ochrony Zabytków.

Hodder, I. 1995

Johnson, M.

2013 Teoria archeologii. Wprowadzenie. Kraków: Wydawnictwo Uniwersytetu Jagiellońskiego.

Kajzer, L.

1994 Archeologia a historia kultury materialnej. Kwartalnik Historii Kultury Materialnej, 2, $173-175$.

Kobyliński, Z.

2003 Quo vadis archaeologia? O przyszłości badań nad przyszłością. Archeologia Polski, 48(1-2), 223-234.

2009 Archeologia wobec wyzwań współczesności. W: Brzostowicz M. (red.), Archeologia polska i jej czasy. Materiały z konferencji zorganizowanej 26 października 2007 roku z okazji 150-lecia Poznańskiego Towarzystwa Przyjaciót Nauki i Muzeum Archeologicznego w Poznaniu (s. 103-131). Poznań: PTPN.

2012 Sytuacja epistemologiczna archeologa a metodyka i metodologia badań archeologicznych. Wprowadzenie. W: S. Tabaczyński, A. Marciniak, D. Cyngot, A. Zalewska (red.), Przeszłość społeczna. Próba konceptualizacji (s. 355-366). Poznań: Wydawnictwo Poznańskie.

2015 Which archaeology does the modern world need? W: K. Kristiansen, L. Šmejda, J. Turek (red.), Paradigm found. Archaeological Theory. Present, Past And Future. Essays Kowalczyk-Heyman, E. in Honour of Evžen Neustupný (s. 156-166). Oxford - Philadelphia: Oxbow Books.

2012 Blaski i cienie współpracy historyków i archeologów średniowiecznych. W: M. Brzostowicz, M. Przybyła, D. A. Sikorski (red.), Archaeologia versus historiam - historia versus archaeologiam. Czyli jak wspólnie poznawać średniowiecze (s. 26-39). Poznań: PTPN.

Kowalska, A. B., Dworaczyk, M. (red.)

2011 Szczecin wczesnośredniowieczny. Nadodrzańskie centrum. Warszawa: Trio.

Kurnatowska, Z.

2012 Wprowadzenie. W: M. Brzostowicz, M. Przybyła, D. A. Sikorski (red.), Archaeologia versus historiam - historia versus archaeologiam. Czyli jak wspólnie poznawać średniowiecze (s. 9-11). Poznań: PTPN. 
Leciejewicz, L.

1991 Społeczeństwo i kultura miast pomorskich w XI-XII wieku. W: L. Leciejewicz (red.), Miasta zachodniostowiańskie w XI-XII wieku. Społeczeństwo - Kultura (s. 205-224).

Le Goff, J. Wrocław - Warszawa - Kraków: Zakład Narodowy im. Ossolińskich.

2015 Historia i pamięć. Warszawa: Wydawnictwo Uniwersytetu Warszawskiego.

Lesure, R. G.

2015 Emplotment as Epic in Archaeological Writing: The Site Monograph as Narrative. Norwegian Archaeological Review, 48(2), 57-74.

Mamzer, $\mathrm{H}$.

2012 Archeologia i historia jako wspólnota interpretacyjna. W: M. Brzostowicz, M. Przybyła, D. A. Sikorski (red.), Archaeologia versus historiam - historia versus archaeologiam.

Marciniak, A. Czyli jak wspólnie poznawać średniowiecze (s. 232-239). Poznań: PTPN.

2011 Przedstawienie i narratywizm w archeologii. W: S. Tabaczyński, A. Marciniak, D. Cyngot, A. Zalewska (red.), Przeszłość spoteczna. Próba konceptualizacji (s. 162-177). Poznań: Wydawnictwo Poznańskie.

2013 O przeszłości. Dylematy przedstawiania w archeologii. Rocznik Antropologii Historii, $1(4), 17-54$.

Marciniak, A., Minta-Tworzowska, D., Pawleta, M.

2011 Współczesne oblicza przeszłości. Wprowadzenie. W: A. Marciniak, D. Minta-Tworzowska, M. Pawleta (red.), Współczesne oblicza przeszłości (s. 9-24), Poznań, Wydawnictwo Poznańskie.

Minta-Tworzowska, D.

2000 Świat archeologii w świetle źródeł archeologicznych. Acta Historica et Museologica. Universitatis Silesianae Opavensis, 5, 49-59.

2012 W jaki sposób ujmować dialog historii i archeologii. Wybrane zagadnienia. W: M. Brzostowicz, M. Przybyła, D. A. Sikorski (red.), Archaeologia versus historiam - historia versus archaeologiam. Czyli jak wspólnie poznawać średniowiecze (s. 116-134). Poznań: PTPN.

Neustupný, E.

2001 The cognitive role of archaeology. W: W. Kobyliński (red.), Quo vadis archaeologia? Whiter European archaeology in the 21st century? (s. 30-36). Warszawa: Wydawnictwo Uniwersyteckie.

Patrik, L.

1985 Is there an archaeological record? Advances in Archaeological Method and Theory, 8, $27-62$.

Rączkowski, W.

2009(2011) Teoria, empiria i praktyka: archeologiczny dyskurs w sieci zależności i opozycji. Analecta Archaeologica Ressoviensia (Thing, Sources, Interpretations. Rzeczy, źródta, interpretacje), 4, 23-33.

2012 Metody w archeologii. W: S. Tabaczyński, A. Marciniak, D. Cyngot, A. Zalewska (red.), Przeszłość społeczna. Próba konceptualizacji (s. 367-408). Poznań: Wydawnictwo Poznańskie.

Renfrew, C., Bahn, P.

2002 Archeologia. Teorie, metody, praktyka. Warszawa: Prószyński i S-ka.

Rębkowski, M.

2005 Kołobrzeg jako modelowy przykład przemian urbanizacyjnych na Pomorzu w XIII w. W: L. Leciejewicz, M. Rębkowski (red.), Salsa Cholbergensis. Kołobrzeg w średniowieczu (s. 47-59). Kołobrzeg: Le Petit Café. 
2008 Czy archeolog odczytuje historię średniowiecza? Uwagi o znaczeniu źródeł archeologicznych. W: S. Suchodolski (red.), Źródła historyczne wydobywane z ziemi (s. 11-31). Wrocław: Chronicon.

Soli, B.

2015 The Site Monograph: Epic, realist or Modern. Norwegian Archaeological Review, 48(2), $75-77$.

Stanisławski, B., Filipowiak W. (red.)

2013 Wolin wczesnośredniowieczny, t. 1. Warszawa: Trio.

2014 Wolin wczesnośredniowieczny, t. 2, Warszawa: Trio.

Strzelczyk, J.

2012 Współpraca historyków i archeologów oczami historyka. W: M. Brzostowicz, M. Przybyła, D. A. Sikorski (red.), Archaeologia versus historiam - historia versus archaeologiam.

Suchodolski, S. Czyli jak wspólnie poznawać średniowiecze (s. 21-39). Poznań: PTPN.

2008 Wprowadzenie. W: Suchodolski S. (red.), Źródla historyczne wydobywane z ziemi (s. 7-9), Wrocław: Chronicon.

Šmejda, L., Baumanová, M.

2015 Conceptual crossroads: community and society in prehistory. W: K. Kristiansen, L. Šmejda, J. Turek (red.), Paradigm found. Archaeological Theory. Present, Past And Future. Tabaczyński, S. Essays in Honour of Evžen Neustupný (s. 47-60). Oxford - Philadelphia: Oxbow Books.

1987 Archeologia średniowieczna. Problemy. Źródta. Metody. Cele badawcze. Wrocław: Zakład Narodowy im. Ossolińskich.

2003 Archeologia wobec szans i pułapek ponowoczesnego świata. Archeologia Polski, 48(1-2), 234-243.

Tokarska-Bakir, J.

2016 Repetytorium z człowieka. Wstęp. W: W. Barnard, Antropologia. Zarys teorii i historii (s. 5-21). Warszawa: PIW.

Topolski, J.

1973 Metodologia historii. Warszawa: PWN.

2000 O interpretacji i nadinterpretacji w archeologii. W: A. Buko, P. Urbańczyk (red.), Archeologia w teorii i praktyce (s. 65-73). Warszawa: IAE PAN.

2008 Jak się pisze i rozumie historię. Tajemnice narracji historycznej. Poznań: ABC.

2016 Teoretyczne problemy wiedzy historycznej. Antologia tekstów. Wybrane przez E. Domańska. Poznań: Wydawnictwo Nauka i Innowacje.

Urbańczyk, P.

2006 Polska archeologia wczesnego średniowiecza a antropologia kulturowa. W: W. Chudziak, S. Moździoch (red.), Stan i potrzeba badań nad wczesnym średniowieczem w Polsce - 15 lat później (s. 31-40). Toruń: Wydawnictwo Naukowe UMK.

2014 Czy historyk może współpracować z archeologiem. W: E. Domańska, R. Stobiecki, T. Wiślicz (red.), Historia - Dziś. Teoretyczne problemy wiedzy o przeszłości (s. 255-264). Kraków: Universitas.

Wendland, $\mathrm{M}$. 2011

Konstruktywizm komunikacyjny. Poznań: Wydawnictwo Naukowe IF UAM.

White, $\mathrm{H}$.

2009 Proza historyczna. Kraków: Universitas.

Wrzosek, W.

1994 Braudelowska idea kultury materialnej. Kwartalnik Historii Kultury Materialnej, 2, 167-172.

2010 Historia - Kultura-Metafora. Powstanie nieklasycznej historiografii. Wrocław: Wydawnictwo Uniwersyteckie. 
Ziembiński, Z.

1997 Logika praktyczna. Warszawa: Wydawnictwo Naukowe PWN.

Ziomek, T.

1990 Retoryka opisowa. Wrocław: Ossolineum.

\title{
NARRATION IN HISTORICAL ARCHAEOLOGY BUILT AROUND THE ARGUMENT: "IN THE LIGHT OF ARCHAEOLOGY"
}

\author{
Sum mary
}

"In the light of archaeology..." means a statement or conclusion based on archaeological sources, its practice and theoretical models used in it. But the range of possibilities and persuasiveness of all such statements is very wide. A typical problem in today's historiographic literature is the writer's failure to define his own research attitude. The issues of whether beliefs influence inferences are often overlooked in silence.

The aim of this article is to discuss the need for a more substantive attention to theoretical assumptions in archaeological writing, especially in the aspect of creating historiographic narratives in historical archaeology. While attention is paid to belonging to a given theoretical trend, the issues of narrative, persuasive procedures and noticing the narrative style that is chosen are less frequently analyzed. These are very significant characteristics of a given text, as they are directly directed to the reader, i.e., the person to whom our research and conclusions are presented.

\section{WHICH ARCHAEOLOGY?}

Colin Renfrew and Paul Bahn wrote in their work, which is a kind of compendium of archaeological knowledge, that "Archaeology is both a natural and a humanistic science" (Renfrew, Bahn, 2002, p. 12). This simple statement clearly shows the problem and the spectrum within which we must approach archaeology and its writing practices today. The problem of self-determination of the degree of scientifying, humanization, anthropologization, interdisciplinarity, etc., rises a serious problem even in the very assumptions in which context the conclusions and hypotheses will be presented.

There are two most important questions for any research, not just in the humanities and social sciences, "What are we trying to discover?" and "What is this knowledge for?" Reflection on the subject of research and the sense of their performance is often not expressed in the works, as it seems unnecessary. The meaning is self-explanatory, and it is difficult to answer the question of what will be discovered before undertaking research (Barnard, 2016, p. 31). This approach is unfortunately evident in archaeology, where discoveries are more post factum than starting with a research question before work begins.

Similarly, with the answer to the question of what the results of the excavations can be used for, or how to place them in the structure of the state of knowledge on a given topic (e.g., whether they confirm any previous assumptions, etc.). It is usually not clearly articulated, which does not integrate our knowledge in a given field.

Also, the limitation to "excavations and describing them" contributes to the situation where there is an extreme approach that explicitly regards archaeology as a "(research) technique" rather than a field of knowledge. Archaeology is used to obtain sources and data that are used by researchers 
of other sciences for inference and interpretation (such as, for example, historians and anthropologists; after Rączkowski, 2012, p. 369-370). This approach is also sometimes supported by the more or less conscious belief that the increase in knowledge in archaeology only proceeds through new excavations and that theoretical reflection is unnecessary.

\section{WHICH MODEL OF COGNITION AND WHAT DO WE CONSIDER ARCHAEOLOGICAL SOURCES IN HISTORICAL ARCHAEOLOGY?}

The problem probably lies at the very foundation of exposing the theory and choosing the adopted model of cognition. Even now in the practice of archaeological research dominate the objectivist model of cognition, which assumes the dualism of the subject and object of cognition, cognitive optimism, the assumption of the continuity of knowledge development, objectivism, empiricism, ahistoricism, etc. We find it all in such research concepts as: diffusionism, evolutionism, historical and cultural archaeology, functionalism, processualism, structuralism, cognitivism, neo-Darwinism, etc. The constructivist model of cognition is in opposition to this, as it evaluates the very objectivity of researchers, and thus considers all cognition subjective, giving the impression of a "postmodern revolution in the perception of archaeology" (Rączkowski 2009 [2011], p. 25). The constructivist model of cognition, however, is loaded with a great deal of theoretical, which is forgotten.

The existing dispute between naturalists and anti-naturalists in archaeology is actually based on the discussion whether the methods of natural sciences accurately reflect the prehistoric reality under study.

When we add to this the constant dispute whether archaeology is a social or historical science, with all the weaknesses of this polarization, we face the problem of choosing and justifying the choice of theoretical foundations. Currently, archaeology can also be treated as a methodological and workshop-based science, thus it can be classified as "science" (this was the intention of the socalled New Archaeology), as a science that is a field of culture (Anglo-Saxon approach to archaeology as anthropology and so-called ethno-archaeology ), or even as a kind of "literature", thus being "text to be read" (Johnson, 2013; Hodder ,1995).

The approach to sources is also a problem. For traditional archaeologists, the world of the past is "reflected" in the sources, and on the basis of these "fossils" it is possible to objectively reconstruct a true, certain image of prehistory (Marciniak, 2013, p. 18). Only as part of the procedural and the so-called the New Archaeology established a kind of "dialogue" with sources, which is best reflected in Ian Hodder's proposal that the past discovered from sources should be less "written" and more "read", because this source is information that we read and interpret hermeneutically (Hodder, 1995, p. 33). Archaeological sources should be understood on two levels: physical (utility, as products that meet human needs) and "textual" (importance in tradition, history and cultural context; Hodder, 1995, p. 218).

Many archaeologists still believe that an archaeological source lacks the stigma of an informant (as is the case with written sources). Thus, it seems more objective and is directly a remnant of the past reality (Minta-Tworzowska, 2000, p. 53), and not just a trace to be read and criticized in our own information reading system. Archaeologists often do not see themselves and their personal "I" in the process of reading sources, their own "informant's stigma", believing in their own objectivity.

Each inference in archaeology requires the realization that there is a very strong relationship between the personal vision, and thus the de facto subjective beliefs of the researcher about the past and history of the world, and the research method and terminology he uses. Such reflection is necessary because only then do we become aware of the number of possible research methods and planes.

The awareness of operating as a basis for inference with a historiographic narrative, which is, however, a creative image of the past, created within the framework of existing sources and beliefs, 
is subject to a margin of probability. Therefore, our knowledge of the past is not pure experience, but mediated information that is subject to subjective opinion and modification depending on the researchers themselves. Histographic narrative is therefore a message understood within a subjective system of concepts.

\section{"HISTORICAL ARCHAEOLOGY" OR "MEDIEVAL STUDIES BASED ON ARCHAEOLOGICAL SOURCES"?}

Archaeology is a historical science, but it is not history. Likewise, history cannot be archaeology. They differ in a different approach to sources as well as a different practice and research methodology. At least that's what you can think of when looking at the traditional approach to research. Meanwhile, the study of historical periods (e.g., the Middle Ages) requires at least a close discourse in both areas, without losing the independence of a given science. Also, late medieval archaeology should combine its analyzes and concepts with conclusions based on written sources and use models borrowed from social sciences, used in the workshop of medievalists.

However, the participation of archaeological research in broadly understood medieval studies is burdened with a certain inconvenience. Medieval archaeology is in such a difficult situation that it has to confront all its discoveries with the existing concepts of historians, creating the impression of researching issues already known and determined long ago on the basis of written sources (Rębkowski, 2008, p. 13). Only that data obtained by archaeologists often change the picture of the Middle Ages or even show a different context that has never been mentioned by historians-medievalists. Most historians-medievalists use almost exclusively written sources, the increase of which is negligible in contrast to subsequent archaeological discoveries. Another problem is a different way of formulating conclusions, even a dialect different for both sciences, which creates misunderstandings (Kurnatowska, 2012, p. 9).

Therefore, the discussion on the relationship between archaeology and history in the 21 st century is essential. This need also arises due to the fact that modern historiography has developed a lot theoretically in recent years, which should also be noted in archaeology. The current historiography opts for the concept of continuity in the historical process, but allows for discontinuation and an alternative path of development, thus replacing the ideas of revolution as discontinuities (Wrzosek, 2010, p. 62). This approach is more reflective and less ideological than the typical understanding of revolution as moments of "dramatic interruption" of the historical process. It also departs from chronological pointing in favor of determining the duration of phenomena and events. It is no longer a specific date, but a period that becomes the basic descriptive unit of a historical process (Wrzosek, 2010, p. 125). Scientist (modernist) historiography also uses the cognition of man from a general level, treating him as part of a community and society. Thus, it recognizes that getting to know the history of a human being is possible through the study of social history, human groups, and accompanying phenomena and processes (ie economy, civilization, social changes; Wrzosek, 2010, p. 134). It is also more self-reflective as it calls for continuous updating of its conclusions.

Both of these disciplines deal with the lives of people in the past, but "the process of gradual specialization of operations carried out on" extracting from the ground "material testimonies and on" off-shelf "verbal sources systematically distanced them from each other (Urbańczyk, 2014, p. 255)". Archaeologists think in terms of "How is something old?", And historians "How long was this event?", dating versus date. This is a very accurate approach to the problem, because usually the dispute actually concerns reading and obtaining sources, where each science, as better prepared to evaluate "its" sources, prioritizes them over others, and possible technical deficiencies are neglected.

The question of the interdisciplinarity of research combining historical and archaeological sources was best, in my opinion, addressed by Jerzy Strzelczyk, who decided that it is better to start 
from the "goal" of research and focus on it to research the sources, and not on the basis of sources, reach the goals and only then combine archaeological data with historical ones. Elżbieta Kowalczyk-Heyman notes that the basic problem in combining the achievements of medieval archaeology and history lies in the misunderstanding of the limitations of both sciences by researchers and the lack of substantive skills and critical inclusion of the achievements of both fields in the course of research conclusions (Kowalczyk-Heyman, 2012, p. 35).

Reconciling these competence disputes between history and archaeology would be to recognize Danuta Minta-Tworzowska that archaeology is both anthropology and history (Minta-Tworzowska, 2012, p. 117). Due to this combination, it can combine a typically anthropological study of "silent" sources and manifestations of everyday life from the past with the use of historical concepts. It is therefore a science more generalizing than history, and in it more features of social science than of historical research. Thus, it is easier for an archaeologist to combine his conclusions with the state of historiography knowledge than for a historian to use the specificity of the image of the past constructed by the archaeologist. Henryk Mamzer does not fully agree with this, considering as I. Hodder that "archaeology is archaeology" (Hodder, 1995, p. 225), i.e., a separate science, although it uses tools from other sciences, from the conceptual workshop, but has its own methods of inference and interpretation. Its way of communicating with other sciences should be a common metalanguage in the field of integrated humanities (Mamzer, 2012, p. 238). This approach is closer to me, although the concept of Danuta Minta-Tworzowska better reflects the practical approach to inference in archaeology. Thus, it recognizes that archaeology is archaeology, but in its functioning it should make extensive use of historical and anthropological concepts, because only in this way we obtain theoretical foundations for creating an image of the past for the use of society.

\section{HISTORICAL OR ARCHAEOLOGICAL NARRATIVE?}

The above question is not unfounded, as there are large differences in research practice and, if such a term can be used, in the style of writing scientific texts.

This, in turn, requires in-depth reflection on the narrative itself. The structure of the historical narrative consists of three layers and this is how historians approach it, and archaeologists rarely reflect on their message in a similar way (Topolski, 2008, p. 288):

- information layers - information about the past;

- persuasive (rhetorical) layers - procedures that authenticate and justify such and not another selection of arguments and information elements;

- ideological-theoretical layers that controls the entire narrative and selection of information.

Wojciech Wrzosek draws attention to the fact that historiography derives from literature, and more precisely from chronicle. Archaeology, through the positivist turn, moved towards quasi-natural science, but due to the specificity of its sources and methodology, it never achieved empirical verifiability typical of natural sciences, and instead of laws it has regularities and generalizations at best. Thus, its constant identity crisis results precisely from this suspension between historiographic (and therefore humanistic) science and science in the sense of science (Wrzosek, 2010, p. 19-21).

The issue of differences in the perception of archaeological and historical writing can be put down to the opinion that historians analyze the texts and write another text, and archaeologists start with material objects and write texts on their basis (Lesure, 2015, p. 58). This is obviously a simplification, but it is a good starting point for a discussion of the similarities throughout historiography and the lack of justification for the insistent distinction between historical narratives and archaeological ones. Using the concept of Hayden White that in historical sciences we meet with the classical narrative (White, 2009), where we deal with an introduction, development and ending, where a sequence of events (arguments, partial conclusions, etc.) is visible, leading to final conclusions it's 
hard not to see the similarities. In archaeology, we usually deal with meta-narrative, top-down or ideological narrative. There is a visible emphasis in archaeological works on presenting the image of the past supported and argued with material remains (Lesure, 2015, p. 60).

It should also be remembered that archaeologists use unaddressed sources (e.g. archaeological ones), which do not have a persuasive layer, but may have a more or less clearly defined ideological and theoretical layer (e.g. the sense of producing a given item or a given state of affairs), which to the historical narrative, they immediately become an element of persuasion (Topolski, 2008, p. 288-289).

Meanwhile, as Zbigniew Kobyliński postulates, "archaeology should be considered a form of social activity closely related to the current reality" (Kobyliński, 2003, p. 224). Archaeology is practiced here and now by researchers living today. It is based on the achievements of past generations, but the emerging conclusions and concepts are based on the current state of knowledge, the cultural paradigm and the competences of researchers.

The archaeological narrative is additionally "epic descriptively" in presenting its analyzes, because a typical monograph in its form aims at the broadest and multifaceted presentation, usually many years of research, where we have many authors and a very wide range of topics, often related only to location. Archaeological work is therefore a multi-threaded work, broad and extensive, but incoherent narrative. Unfortunately, usually conclusions are rarely more than just a declaration of the issues contained or a simple summary.

The problem is therefore the issue of a broader interpretation and creation of a comprehensive picture of the content presented. It is not about creating a "grand narrative" mostly based on assumptions and hypotheses. The idea is to create conclusions that connect individual analyzes. Such that, for example, the description of material culture would be the basis for the analysis of, for example, contacts and changes in the community, and not just a summary of the excavations, where each researcher described the material falling within his field of specialization, without trying to synthesize the results of any analyzes.

The monograph is supposed to be "great", both in terms of content and form, but it is more difficult to find specific and comprehensive content. Therefore, traditional archaeological monographs do not take the form of extensive model analyzes. They are closer to the realistic narrative from the nineteenth century, where a lot of emphasis was placed on the presentation of everyday life and reality in its ordinaryness in selected spheres and ranges. Looking at the method of creating an archaeological narrative, where the results of research and analyzes concerning, for example, a given site are presented, one may wonder whether this is not an unconscious reference to classic narrative concepts, where the researcher resembles a "typesetter", which of the "facts-letters" he arranges their conclusions, selecting them appropriately to confirm or refute a thesis (Topolski, 2008, p. 21). Similarly, the archaeologist uses the results of his research (artifacts, traces of settlement, analyzes, etc.) in the context of the state of knowledge he possesses and acknowledges to create a message in "his" language.

\section{CONCLUSIONS}

The aim of this article is not to negate the entire achievements of historical archaeology, but to discuss the need for greater self-reflection among researchers, who should at least answer the question about a more or less conscious baggage of subjective beliefs and shared views on the subject of the workshop of historical archaeology that affect their inference. They should also look at their work in terms of creating narratives and conclusions that are "created" by them. Archaeological works are a utility text and this awareness cannot be ignored. 
When we use the phrase "in the light of archaeology..." in the archaeological narrative, it means: "in the light of the way I understand and practice archaeology...", a sentence burdened with subjectivity, the outline and characteristics of which should be aware of and inform the reader.

This discretionary meaning requires deeper reflection. First, it requires defining your approach to assessing the image of the past reality. Is it constructed by us, or is it read directly on the basis of sources and analogies, or do we trust, for example, Braudel's concept of routine everyday life?

Another issue is the question of whether our research concerns objects, the creator-user relationship and the thing, or whether we only study human communities, considering their products as premises for reading, where artifacts become a specific cognitive medium, and not the subject of the study itself.

It is also impossible not to pay attention to the problem of narration and the "stigma of the informant" in archaeological writing. Asking yourself questions about the purpose of a given description and what content we want to present is necessary. Such self-reflection allows us to notice the most important issue, i.e., the purposefulness of our inference.

We should also define our approach to the discourse of historical archaeology with history. History is more "literary" and less categorizing, so it does not create a lot of charts, tables and classifications. I am not concerned with creating the impression that history is "more attractive", but with a certain characteristic that is evident in traditionally practiced archaeology, where we are dealing with a "frozen image" and not a historical process as it is in history. This "petrification" of representation in archaeology does not, however, eliminate the need to care for the style of the narrative and its comprehensibility. Categorization and an extensive classification apparatus do not exempt from the need to conclude and present comprehensive conclusions.

According to the above considerations, this text is a commentary on the existing state and an attempt to draw attention to the need for the most conscious approach to one's own scientific workshop. Self-reflection allows for a more justified use, especially in historical archaeology, of the phrase "in the light of archaeology...", because it is followed by a specific concept, also the way of creating a narrative and a subjective approach, and not just a reference to the general research tradition. 